\title{
The UN and the Post-War Global Order: Dumbarton Oaks in Historical Perspective after 75 years
}

\author{
J Simon Rofe, SOAS University of London, \\ Giles Scott-Smith, University of Leiden, \& \\ Tom Zeiler, University of Colorado Boulder
}

The history of 'Dumbarton Oaks' is overshadowed in the formation of the postwar order, most notably by the San Francisco conference of April 1945 that gave birth to the United Nations Organisation. Yet in a number of important ways it was the Dumbarton Oaks conference, or the "Washington Conversations on International Peace and Security Organization" to give it its full and formal title, that fundamentally shaped a "postwar international organisation". In other words, the United Nations, an omnipresent feature of international affairs since 1945, owes a considerable debt to the gathering in the late summer and early autumn of 1944. The Conversations took place in stressed circumstances, with the military outcome of the war still far from determined, ${ }^{1}$ the importance of individual national interests for the protagonists, and the competing viewpoints on an international organisation in the aftermath of the experience of the League of Nations all playing a role. Nonetheless all present understood the opportunity that existed in the late summer of 1944. That the United Nations Organisation has had a mixed record since should not cloud assessments of the scale of the achievement at Dumbarton Oaks to produce a meaningful blueprint for a universal international organisation.

\footnotetext{
${ }^{1}$ The military situation from August-October 1944 was pressing: the Allies failed with Operation Market Garden in the Netherlands to break through on the Western front; Soviet forces were unable or unwilling to offer support to the Warsaw uprising, leaving the Poles to face Nazi Germany's reprisals in the city; in the Pacific US forces were meeting strong resistance from Japanese forces. If the outcome of the war was fairly certain, the end of the war was - militarily - still some way off in the autumn of 1944.
} 
Dumbarton Oaks' place in the panoply of wartime conferences has suffered in comparison with other UN-related gatherings such as Bretton Woods and Hot Springs that led to more readily identifiable results. Dumbarton Oaks, in contrast, was an interim meeting on the way to something bigger, a 'pre-summit meeting. ${ }^{2}$ The value of the accounts presented here is that they reveal the essential wider context and the broader implications to those policy negotiations. It was the practical policy outcomes that were so important to the delegates from the Soviet Union and the United Kingdom that joined those from the United States in their secluded Washington surroundings from 21 August - 28 September (the Chinese nationalist delegation joined the second phase of the conversations from 29 September to 8 October). The articles gathered here indicate how national interests both shaped and were shaped by the emerging international organization for the post-war world.

This special issue of the J ournal of Contemporary History re-evaluates the significance of those meetings in the Georgetown suburbs of Washington DC for the history of global governance. The Dumbarton Oaks estate provided a suitable retreat for the delegates in 1944 who deliberated on the future international organisation. The estate had been donated to Harvard University by the Republican career diplomat, Robert Woods Bliss and his wife Mildred in 1940 for use as a research institute primarily devoted to Byzantine and other ancient cultures. The Bliss's explicit purpose, inscribed in a plague adorning the building to this day, was that by exploring the past it would help 'clarify an everchanging present and to inform the future with wisdom'. Such a mantra underpins the reappraisals presented here.

Previous explorations of Dumbarton Oaks have been limited in both focus and scope. The narrative of the United Nations Organisation typically begins with the Conference in San Francisco in the aftermath of Franklin

\footnotetext{
2 See Jan Melissen, ‘Summit Diplomacy Coming of Age’, Discussion Papers in Diplomacy, Netherlands Institute of International Relations 'Clingendael', 2006.
} 
Roosevelt's death, on the verge of Victory in Europe Day (8 May). ${ }^{3}$ Much of the literature on the Second World War, and separately the Cold War, overlooks the links between strategic military and political thinking that came together at Dumbarton Oaks. This was a panoptical diplomatic moment, with the participating delegates simultaneously looking in all directions. It was a critical juncture in connecting the pre-war, wartime and post-war eras. The relative absence of Dumbarton Oaks from literatures on the Second World War and the Cold War is surprising. It is worth noting that its twin conference, Bretton Woods, or The United Nations Monetary and Financial Conference' (1-22 J uly 1944), has received far greater attention in recent scholarship, with extensive studies of both the main protagonists and the wider diplomatic and policy implications. ${ }^{4}$ This can partly be explained by the relative success of Bretton Woods in laying the groundwork for a stable postwar global economy with the US at its centre, as opposed to Dumbarton Oaks that is associated with the failure of the subsequent United Nations to establish an equally stable international political framework. Nevertheless, this should not undermine historical investigation of the Washington Conversations as a seminal moment for framing international security and global governance, and one that is not solely coloured by the Cold War. Is the historical record exhausted?

The official record of US involvement in Dumbarton Oaks can be found in the Foreign Relations of the United States series, published in $1966 .{ }^{5}$ Since

\footnotetext{
${ }^{3}$ Franklin Roosevelt's individual endeavours to shape the post war world have received attention, see for instance John Lamberton Harper, The Cold War (Oxford: Oxford University Press, 2011); Frank Costigliola, Roosevelt's Lost Alliances: How Personal Politics helped start the Cold War (Princeton: Princeton University Press, 2012).

${ }^{4}$ Ben Steil, The Battle of Bretton Woods: John Maynard Keynes, Harry Dexter White, and the Making of a New World Order (Princeton University Press, 2013); Ed Conway, The Summit: The Biggest Battle of the Second World War (London: Little Brown, 2014); Eric Rauchway, The Moneymakers: How Roosevelt and Keynes ended the Depression, Defeated Fascism, and Secured a Prosperous Peace (New York: BasicBooks, 2015); Eric Helleiner, Forgotten Foundations of Bretton Woods - International Development and the Making of the Postwar Order (Cornell University Press, 2015); Giles Scott-Smith and J. Simon Rofe (eds), Global Perspectives on the Bretton Woods Conference and the Post-War World Order (New York: Palgrave, 2017); Naomi Lamoreaux and Ian Shapiro (eds.), The Bretton Woods Agreement together with Scholarly Commentaries and Essential Historical Documents (New Haven: Yale University Press, forthcoming).

${ }^{5}$ Foreign Relations of the United States: Diplomatic Papers, 1944, General, Vol. 1 (Washington DC: US Government Printing Office, 1966), available at <https://history.state.gov/historicaldocuments/frus1944v01>.
} 
then, Dumbarton Oaks has only received occasional interest from international historians. Robert Hilderbrand's 1990 book, Dumbarton Oaks: The Origins of the United Nations and the Search for Postwar Security, places considerable emphasis on post-war security and the United Nations. ${ }^{6}$ Written at the end of the Cold War, it is a detailed account of the negotiations between the different protagonists at Dumbarton Oaks. However, Hilderbrand's account is now almost thirty years old. Likewise, Ernest May and Angeliki E. Laiou's collection of conference proceedings commemorating the $50^{\text {th }}$ anniversary of Dumbarton Oaks is more than twenty years old. Like Hilderbrand, it reflects the post-Cold War moment of the 1990s, calling on contributors to re-evaluate the conference's significance without the weight of Cold War divisions clouding the analysis. A more holistic view of wartime planning was provided by Georg Schild, who combined his study of Bretton Woods and Dumbarton Oaks to argue that US views of post-war security should be viewed simultaneously in both economic and political terms. ${ }^{7}$ Dumbarton Oaks makes a significant appearance in a number of broader survey pieces, but equally is overlooked in others. It is treated with some depth in Robert Dallek's unparalleled grand study of FDR's foreign policy in focusing upon the President's believe in the 'Four Policemen'. ${ }^{8}$ Andrew Preston's comprehensive look at religion and foreign policy also includes a section on philosopher Reinhold Niebuhr's realism, and the skepticism he shared with foreign policy advisor J ohn Foster Dulles over the workability of an international peace organization in a selfish world. ${ }^{9}$ On the other hand, Dumbarton Oaks is absent from Frank Ninkovich's Modernity and Power or

\footnotetext{
As of 2018, the Documentary History series of the FDR presidency has not produced a volume on the origins of the UN or the Dumbarton Oaks conference, although a volume on Bretton Woods has been released: George McJimsey (ed), Documentary History of the Franklin D. Roosevelt Presidency, Vol. 40: The Bretton Woods Conference, 1944 (LexisNexis, 2008).

${ }^{6}$ Robert C. Hilderbrand, Dumbarton Oaks: The Origins of the United Nations and the Search for Postwar Security (Chapel Hill: University of North Carolina Press, 1990).

${ }^{7}$ Georg Schild, Bretton Woods and Dumbarton Oaks: American Economic and Political Postwar Planning in the Summer of 1944 (New York: St. Martins Press, 1996).

${ }^{8}$ Robert Dallek, Franklin D. Roosevelt and American Foreign Policy, 1932-1945 (Oxford 1979), 466-67, 47879, 507-508.

${ }^{9}$ Andrew Preston, Sword of the Spirit, Shield of Faith: Religion in American War and Diplomacy (New York 2012), 352-401.
} 
Andrew Bacevich's studies of American empire and the American Century. ${ }^{10}$ Neither does it surface in Norman Graebner's collection of essays from the 1980s on America as a world power or in the most recent edition of Stephen Ambrose's (with Douglas Brinkley) Rise to Globalism. ${ }^{11}$ Scattered articles have appeared over the years, and memoirs have added more details to the historical record, but the literature is still relatively thin. ${ }^{12}$

The articles collected here present new directions for exploring its historical significance. Firstly, there is the issue of periodization. Recent historical writing has challenged the neat book-ends of 1945 and 1989 for the Cold War, and the Dumbarton Oaks conference likewise represents the ongoing development of a discourse on the shape of international affairs that transcended the interwar period. In short, a new context for the conference which recognised the 'moment' that existed in August 1944 for strategic thinking about the future amid the fulcrum of global conflict. ${ }^{13}$ Secondly, there is a decentering of the US role as the central player in international history. Whilst this has taken place in Cold War histories authored by the likes of Odd Arne Westad and Lorenz Luthi, the articles here push the process further to emphasise the important involvement of others - particularly the Soviet Union, and, with China, what would become the non-aligned nations - in

\footnotetext{
${ }^{10}$ Frank Ninkovich, Modernity and Power: A History of the Domino Theory in the Twentieth Century (Chicago 1994); Andrew J. Bacevich, American Empire: The Realities and Consequences of U.S. Diplomacy (Cambridge, MA 2002).

${ }^{11}$ Norman A. Graebner, America as a World Power: A Realist Appraisal from Wilson to Reagan (Wilmington 1984); Stephen A. Ambrose and Douglas G. Brinkley, Rise to Globalism: American Foreign Policy Since 1938 ( $9^{\text {th }}$ rev. edn. 2010).

${ }^{12}$ See for instance Sidney Bradshaw Fay, 'The Dumbarton Oaks Conference,' Current History 7 (1944) 257264; Edwin Borchward, 'The Dumbarton Oaks Conference,' American Journal of International Law 39 (1945) 97-101; A. Roshsnin, 'The Dumbarton Oaks Conference,' International Affairs 25 (1979) 67-74; Charles Bohlen, Witness to History 1929-1969 (New York: Norton, 1973).

${ }^{13}$ For recent works that explore this transition period, see Patricia Clavin, Securing the World Economy: The Reinvention of the League of Nations 1920-1926 (Oxford: Oxford University Press, 2013). In addition to Clavin, recent works that have contributed to this reappraisal include Barbara Keys, Globalizing Sport: National Rivalry and International Community in the 1930s (Cambridge MA: Harvard University Press, 2006); Mark Mazower, No Enchanted Palace (Princeton: Princeton University Press, 2008); Zara Steiner, The Triumph of the Dark: European International History 1933-1939 (Oxford: Oxford University Press, 2011); Daniel Gorman, The Emergence of International Society in the 1920s (Cambridge: Cambridge University Press, 2012); Katharina Rietzler, 'Before the Cultural Cold Wars: American Philanthropy and Cultural Diplomacy in the Interwar Years,' Historical Research 84 (February 2011), 148-164; Justin Hart, Empire of Ideas: The Origins of Public Diplomacy and the Transformation of U.S. Foreign Policy (New York: Oxford University Press, 2013).
} 
defining terms and outlining pathways for the future international order. ${ }^{14}$ Thirdly, there is the intermestic angle. US public opinion had to be acclimatised to another venture for setting the terms for world order, following what has often been perceived as the failed Wilsonian gambit of 1918-1920. ${ }^{15}$ The US government could not step out without ensuring that the American public - read, the electorate - was on board. ${ }^{16}$ Fourthly, there is the issue of the global impact. Similar to Versailles twenty-five years earlier, the negotiations of Dumbarton Oaks were followed by many around the world who were not present but who had a definite stake in, and opinion on, how the post-war world should be transformed and organised. Gender and racial equality were very much an issue, in terms not only of the future of the European empires but also of who was deciding on that future. ${ }^{17}$ The Washington Conversations resonated far beyond their Washington DC location. Lastly, there is the institutional history. Dumbarton Oaks laid out a blueprint for a global international organisation that would be finalized at San Francisco eight months later. The security challenges of the post-war world, particularly once the anti-fascist coalition broke into opposing spheres of influence, forced the nascent UN to adopt a role that was diminished from the one envisaged at Dumbarton Oaks. Nevertheless, those who ran the UN adapted to these difficult circumstances in order to give meaning, purpose, and identity to the new organisation in world politics. ${ }^{18}$

\footnotetext{
${ }^{14}$ Odd Arne Westad, Global Cold War: Third World Interventions and the Making of Our Times (Cambridge, 2005); Lorenz Luthi, The Regional Cold Wars in Europe, East Asia, and the Middle East: Crucial Periods and Turning Points (Woodrow Wilson Center Press with Stanford University Press, 2015).

${ }^{15}$ See Ashley Cox, Wilsonian Approaches to American Conflicts: From the War of 1812 to the First Gulf War (New York: Routledge, 2017).

${ }^{16}$ See Andrew Johnstone, Against Immediate Evil: American Internationalists and the Four Freedoms on the Eve of World War II (Ithica: Cornell University Press, 2014) and Andrew Johnstone, Dilemmas of Internationalism: The American Association for the United Nations and US Foreign Policy, 1941-1948 (Abingdon: Routledge, 2009).

${ }^{17}$ See the work of the Center for International Studies and Diplomacy entitled 'Women and the UN Charter', https://www.soas.ac.uk/cisd/research/women-and-the-un-charter/; Erez Manela, The Wilsonian Moment: SelfDetermination and the International Origins of Anticolonial Nationalism (Oxford: Oxford University Press, 2007); Penny von Eschen, Race against Empire: Black Americans and Anticolonialism 1937-1957 (Ithaca: Cornell University Press, 1997), 75.

${ }^{18}$ The UN is gathering more attention within the recent trend of research on the role of international organisations in international history. See Sandrine Kott, 'Les organisations internationales, terrains d'étude de la globalisation. Jalons pour une approche socio-historique', Special Issue of Critique internationale 3 (2011); Alanna O'Malley, The Diplomacy of Decolonisation: America, Britain, and the UN during the Congo Crisis 1960-1964 (Manchester: Manchester University Press, 2018).
} 
To explain the new directions in historical understanding of the Dumbarton Oaks conversations an overarching reappraisal is both necessary and useful. A realist perspective that focuses on states' self-interest, ${ }^{19}$ sees the predominance of Great Powers in the Conversations in the late summer of 1945. Those who had led the United Nations forces against the Axis powers the United States, the Soviet Union, Great Britain, along with the secondary power of China - dominated the process. George Kennan wrote from Moscow to US Secretary of State Cordell Hull that a realistic foreign policy must prevail; 'we must not fail the people of the Western nations with UN plans from Dumbarton Oaks that failed to occupy ourselves seriously and minutely with the sheer power relationships of the European peoples. ${ }^{20}$ It is instructive to recall that at the same time the Washington Conversations were occurring, FDR and Churchill were meeting at their last bilateral summit, the second Quebec conference. For four days in September, this meeting, code-named Octagon, focused on hard-headed postwar topics like occupation zones in defeated Germany and the Morgenthau Plan for the 'pastoralisation' and demilitarisation of Germany, as well as on strategic decisions about the ongoing war in Europe and Asia. Following Quebec, Churchill and Roosevelt met at the President's home in Hyde Park, New York to collaborate on the atomic bomb, and did so in secret, as representatives of two Great Powers practicing traditional secret diplomacy. Two days after the conclusion of the Dumbarton Oaks talks, Churchill travelled for a ten-day visit with Stalin for the fourth Moscow meeting, the Tolstoy Conference', to deal not only with Soviet entry into the war against J apan but also about the future of Poland. Most famously, the two realist statesmen sketched postwar spheres of influence in Eastern Europe through their infamous 'naughty document', in

\footnotetext{
${ }^{19}$ Literature on 'Realism' in International Relations is plentiful with Keohane and Waltz featuring most prominently. Amongst the most accessible accounts is Scott Burchills' chapter in 'Theories of International Relations' (5 $5^{\text {th }}$ Edition, New York: Palgrave Macmillan, 2013), 57-87.

${ }^{20}$ David J. Stone, War Summits: The Meetings That Shaped World War II and the Postwar World (Washington, D.C. 2005), 179 .
} 
Churchill's words, otherwise known as the 'percentages agreement', that divided the region between Great Britain and the USSR. ${ }^{21}$

Dumbarton Oaks itself was not a sideshow in this theatre of formal and informal great power summits. After all, the most famous occurrence during the conference was the request by Soviet Ambassador to the United States, Andrei Gromyko, for the seating of all Soviet Republics in the postwar security organization. That bombshell has been interpreted by some as an expression of Russian fear of being isolated by the capitalists after the war. After all, the British had their dominions and the Americans could muster their western hemisphere neighbours to the south to vote their way. Stalin needed obedience from some reliable bloc, and thus he had Gromyko issue his bold demand, one that nearly derailed the negotiations before a compromise deal was made later to his satisfaction. This was a harbinger of things to come, and indicated a great power divide that had been conspicuously absent at Bretton Woods. ${ }^{22}$

Such a hard-nosed approach was perhaps unsurprising given that as the Conversations began, military matters were still to the fore. The ferocity of the fighting as the Allies made progress through Northern France, on the Eastern front (most tragically in the Warsaw uprising), and in the Pacific as US Forces island-hopped their way towards J apan, fundamentally challenged thinking for a peaceful post-war world. The context for Dumbarton Oaks, in other words, included war and its spoils. Idealism was not foremost in the minds of leaders as the war ground on, and as big powers eyed territory for future profit, influence, and security. The idealism of achieving a breakthrough for a new institutional framework for global governance was therefore severely tempered by realist goals on the ground.

The articles that follow here recognise this tension between the ideal of a United Nations and one governed by balance of power politics amongst the Great Powers. Stephen Wertheim presents the case that the emergent United

\footnotetext{
${ }^{21}$ Eugene L. Rasor, Winston S. Churchill, 1874-1965: A Comprehensive Historiography and Bibliography $\left(2^{\text {nd }}\right.$ edn. Santa Barbara 2000), 269.

${ }^{22}$ See Vladimir Pechatnov, 'The Soviet Union and the Bretton Woods Conference', in Scott-Smith and Rofe (eds.), Global Perspectives on the Bretton Woods Conference, 89-107.
} 
Nations Organisation was a means to facilitate US leadership of a 'postwar world'. In making this argument Wertheim ties together two important dimensions of the postwar world, US foreign policy and the importance of domestic public opinion. Conditioned by the experience of the American public's reaction after the First World War, policy makers wanted to ensure that US post-war leadership would be accepted, if not welcomed.

Andrew J ohnstone's article further augments our historical understanding of the role of US public opinion. His article addresses the concerted but distinct efforts of US officials and unofficial private internationalists to present Dumbarton Oaks to the American public. The efforts to educate public opinion revealed tensions in both government circles and amongst private internationalist bodies over differing interpretations of how the international organisation sketched at Dumbarton Oaks would function.

While these two articles have a US focus, Geoffrey Robert's article draws upon previously unavailable sources to reveal Soviet thinking on an international organisation that was framed around post-war collaboration of the Great Powers. It exposes the influence of Soviet foreign commissar Vyacheslav Molotov in relation to J osef Stalin, and points to the former's consideration of a unified Germany and possibilities for a pan-European collective security system.

An equally innovative approach is provided by Stefanie Wichhart's analysis of the influence of Dumbarton Oaks upon the formation of the Arab League in March 1945 through the Alexandria Protocol. The inspiration to pursue a pan-Arab nationalist cause by those gathered in Egypt can clearly be sourced back to the negotiations that took place in the Washington suburb the previous year. Drawing upon Arab sources alongside those from Britain and the United States, Wichhart's analysis points to how small, medium and regional powers saw potential in the unfolding international organisation. Disappointment with the short-term outcome of Dumbarton Oaks manifested 
itself in Arab approaches in San Francisco and to overall frustration with the United Nations as the Cold War took hold later in the 1940s.

Moving attention to the internal mechanisms of the future organisation, Robbie Barnes focuses upon the shape of the Secretariat and the Secretary General as conceived in 1944 and later as it faced its first substantial security challenge in the case of the Korean War. The distance between what was proposed in 1944 and the reality of a United Nations which failed to maintain great power cooperation into the post-war world becomes evident here. Equally, exploiting the absence of great power dialogue in the United Nations, the first Secretary-General Trygve Lie established efforts for post-war reconstruction in Korea through the UN Commission for the Unification and Rehabilitation of Korea and the UN Korean Reconstruction Agency, which set a precedent for subsequent UN endeavours.

These articles therefore provide a reappraisal of the Dumbarton Oaks moment 75 years on, positioning it within a broader international historical context than has up till now been the case. In doing so they contribute to the ongoing revisionism in UN history, reinterpreting the origins of this much maligned but nevertheless essential apparatus for international diplomacy. ${ }^{23}$

\section{Articles}

- J Simon Rofe - SOAS University of London, Giles Scott-Smith - University of Leiden, \& Tom Zeiler - University of Colorado

The UN and the Post-War Global Order Dumbarton Oaks in Historical Perspective after 75 Years

- Stephen Wertheim - Columbia University/ University of Cambridge

Instrumental internationalism: The United Nations as America's will to lead the world

- Dr Andrew J ohnstone - University of Leicester

Seizing the Second Chance: Selling Dumbarton Oaks to the American Public

\footnotetext{
${ }^{23}$ See for instance Dan Plesch and Thomas Weiss, eds., Wartime Origins and the Future United Nations (London: Routledge, 2015).
} 
- Professor Geoffrey Roberts - University College Cork Stalin and the Dumbarton Oaks Conference: The Soviet Origins of the United Nations

- Dr Stefanie Wichhart - Niagara University

The Arab Response to Dumbarton Oaks and the Formation of the Arab League

- Dr Robbie Barnes - York St J ohn University

The UN Secretariat and the Korean War 